\title{
Prevalence of Infection with the Larval Form of the Cestode Parasite Taenia saginata in Cattle in Northwest Iran and its Zoonotic Importance
}

\author{
Sestod Paraziti Olan Taenia saginata Larvasından Kaynaklanan Enfeksiyonun Kuzeybatı
} İran'da Prevalansı

\author{
Mohammad Mirzaei', Ahmad Nematolahi², Javad Ashrafihelan², Hadi Rezaei ${ }^{3}$ \\ 1Department of Pathobiology, Faculty of Veterinary Medicine, Shahid Bahonar University of Kerman, Kerman, Iran \\ 2Department of Pathobiology, Faculty of Veterinary Medicine, Tabriz University, Tabriz, İran \\ ${ }^{3}$ Department of Pathobiology, Faculty of Veterinary Medicine, Urmia University, Urmia, İran
}

\section{ABSTRACT}

Objective: Bovine cysticercosis is a cattle infection caused by a tapeworm, Taenia saginata. While the condition is relatively innocuous, the parasite infects the small intestine of humans in its mature stage and causes a few specific symptoms such as abdominal pain and nausea. Methods: Between February 2013 and February 2014, a total of 640 cattle were randomly selected from all the cattle sent to the abattoir and some internal organs and skeletal muscles of these cattle were inspected.

Results: Overall, $11(1.71 \%)$ cattle were infected with the larval form of the cestode parasite T. saginata. In addition, the infection was more prevalent in cattle aged above 12 months than in those aged below 12 months [10 (2.06\%) vs. $1(0.64 \%)$. The prevalence of infection was significantly higher in female animals [8 (3.72\%)] than in male animals [3 $(0.70 \%)](p<0.05)$. However, no significant difference was found between the rates in the 2 age groups or in different seasons. While the infections were detected in several visceral organs, no significant difference was found between their infection rates.

Conclusion: The comparatively high prevalence of Cysticercus bovis infection in the cattle in Tabriz, Iran, may contribute to economic and health problems in the country's meat industry. On the other hand, the role of public health education in $\mathrm{C}$. bovis infection control cannot be neglected.

Keywords: Prevalence, Cysticercus bovis, Cattle, Iran

Received: $15.04 .2016 \quad$ Accepted: 11.10 .2016

\section{Öz}

Amaç: Bovine cysticercosis (tenya hastalığı), Taenia saginata bağırsak kurdundan kaynaklanan bir sığır enfeksiyonudur. Bu hastalık nispeten tehlikesiz olmasına rağmen, parazit olgun aşamadayken insanlarda ince bağırsağı enfekte edebilir ve karın ağrısı ve mide bulantısı gibi bazı spesifik semptomlara yol açabilir.

Yöntemler: Şubat 2013 ile Şubat 2014 tarihleri arasında, mezbahaya gönderilen tüm sığırlar içerisinden toplam 640 sığır rasgele seçildi. Bu hayvanların bazı iç organları ve iskelet kasları incelendi.

Bulgular: Genel olarak, 11 (\%1.71) sığır sestod paraziti olan Taenia Saginata larvasından enfekte oldu. Ayrıca enfeksiyon, 12 aydan küçük hayvanlarla karşılaştııılığında, 12 aydan büyük hayvanlarda daha yaygındı [10 (\%2.06) vs. 1 (\%0.64)]. Enfeksiyon prevalansı dişi hayvanlarda [8 (\%3.72)] erkek hayvanlardan [3 (\%0.70)] anlamlı derecede daha yüksekti ( $p<0.05)$. Ancak, yaş grupları veya farklı mevsimler açısından enfeksiyon oranlarında anlamlı bir farklılık bulunmadı. Enfeksiyon bazı iç organlarda araştııılığında, enfeksiyon oranlarında anlamlı bir farklılık saptanmadı.

Sonuç: Tebriz, İran'da sığırlarda oldukça yüksek olan Cysticercus bovis enfeksiyonu prevalansı ülkenin et endüstrisinde ekonomik ve sağlık problemlerine yol açabilir. Diğer yandan, halk sağlığı eğitiminin C. bovis enfeksiyonunun kontrolüne katkısı göz ardı edilemez.

Anahtar Kelimeler: Prevalans, Cysticercus bovis, Sığır, Iran

Geliş Tarihi: 15.04.2016

Kabul Tarihi: 11.10.2016

Address for Correspondence / Yazışma Adresi: Mohammad Mirzaei E.posta: dr_mirzaie_mo@yahoo.com DOI: 10.5152/tpd.2016.4776

OCopyright 2016 Turkish Society for Parasitology - Available online at www.tparazitolderg.org

@Telif hakkı 2016 Türkiye Parazitoloji Derneği - Makale metnine www.tparazitolderg.org web sayfasından ulaşılabilir. 


\section{INTRODUCTION}

Cysticercosis caused by Taenia saginata in cattle creates veterinary and public health problems in Iran. This cestode parasite was first reported from Iran as early as 1938 by Endrajat (1, 2).

Bovine cysticercosis is an important zoonotic disease and can cause economic loss. It is distributed throughout Iran, especially in rural areas $(1,3)$. This disease is a relatively innocuous parasitic zoonosis caused by the larvae of $T$. saginata, commonly known as beef tapeworm. The larvae enter the human body through the ingestion of undercooked or raw beef. The parasites at their mature stages infect the small intestine of humans and result in tissue infection and some specific symptoms such as abdominal pain and nausea. T. saginata is an important zoonotic species belonging to the genus Taenia, and the larval stage of this parasite is known as Cysticercus bovis. C. bovis is found mainly in the muscles of cattle and buffaloes, and the small intestine is the predilection site of adult tapeworms in their human hosts $(5-8)$.

In the meat industry, economic loss is closely related to the infection status. In fact, a carcass with a heavy infection or generalized cysticercosis must be completely discarded. Meanwhile, light infection or localized cysticercosis necessitates not only the condemnation of the infected parts but also the storage of the remaining parts at lower than $-7^{\circ} \mathrm{C}$ for up to 3 weeks to inactivate the parasites $(9,10)$. Because bovine cysticercosis does not generally manifest any clinical signs in the cattle, post-mortem inspection of the predilection sites is required to ensure the absence of the parasite. Although predilection sites are commonly examined in areas where regular post-mortem screening is performed, such measures are not adequately sensitive, especially for the detection of light infections (11, 12). Some researches on bovine cysticercosis have previously been conducted in Iran (1,3). Tabriz, the capital of East Azerbaijan Province, Northwest Iran, is one of the important areas for training domestic animals. Therefore, in view of obtaining new information on the prevalence of cysticercosis in slaughtered cattle at the Tabriz slaughterhouse and the associated economic losses, this research was conducted in Tabriz city, Northwest Iran.

\section{METHODS}

The present study was conducted in Tabriz from February 2013 to February 2014. In total, 640 cattle were randomly selected from all the cattle sent to the abattoir, and their internal organs, including the omentum, triceps, thigh muscles, masseter muscle, heart muscle, intercostal muscles, liver, and tongue, were inspected. The inspections were conducted over a 1-year period (spring-winter). Before inspections, the age and sex of the cattle were determined on the basis of their teeth characteristics and physical appearance. Normal meat inspection procedures were also implemented on the slaughtered animals (13). The observed cysts were carefully dissected from the tissues, and their number in different organs was separately recorded for each animal. The slaughtered animals were examined using both routine and detailed visual inspection measures (9). Chi-square test was applied to compare
Table 1. Prevalence of Cysticercus bovis in different organs of slaughtered cattle

\begin{tabular}{|c|c|c|c|}
\hline Organ & & $\begin{array}{c}\text { Frequency of } \\
\text { Cysticercus bovis }\end{array}$ & $p$ \\
\hline \multirow{3}{*}{ Liver } & Male & $0(0 \%)$ & $p>0.05$ \\
\hline & Female & $1(0.15 \%)$ & \\
\hline & Total & $1(0.15 \%)$ & \\
\hline \multirow{3}{*}{ Omentum } & Male & $0(0 \%)$ & \\
\hline & Female & $0(0 \%)$ & \\
\hline & Total & $0(0 \%)$ & \\
\hline \multirow{3}{*}{ Intercostal muscle } & Male & $0(0 \%)$ & \\
\hline & Female & $1(0.15 \%)$ & \\
\hline & Total & $1(0.15 \%)$ & \\
\hline \multirow{3}{*}{ Masseter muscle } & Male & $1(0.15 \%)$ & \\
\hline & Female & $3(0.46 \%)$ & \\
\hline & Total & $4(0.62 \%)$ & \\
\hline \multirow{3}{*}{ Triceps muscle } & Male & $0(0 \%)$ & \\
\hline & Female & $1(0.15 \%)$ & \\
\hline & Total & $1(0.15 \%)$ & \\
\hline \multirow{3}{*}{ Heart muscle } & Male & $0(0 \%)$ & \\
\hline & Female & $1(0.15 \%)$ & \\
\hline & Total & $1(0.15 \%)$ & \\
\hline \multirow{3}{*}{ Thigh muscle } & Male & $0(0 \%)$ & \\
\hline & Female & $1(0.15 \%)$ & \\
\hline & Total & $1(0.15 \%)$ & \\
\hline \multirow{3}{*}{ Tongue } & Male & $0(0 \%)$ & \\
\hline & Female & $2(0.31 \%)$ & \\
\hline & Total & $2(0.31 \%)$ & \\
\hline Total & & $11(1.71)$ & \\
\hline
\end{tabular}

the calculated percentages. All statistical analyses were performed in Statistical Package for the Sciences for Windows 16.0 (SPSS Inc.; Chicago, IL, USA), and $p<0.05$ was accepted as statistically significant.

\section{RESULTS}

Overall, 640 cattle, including 425 males and 215 females, were examined. A total of 11 cattle (1.71\%), 3 males $(0.70 \%)$ and $8 \mathrm{fe}-$ males (3.72\%), were positive for $C$. bovis. In addition, the infection was more prevalent in cattle aged above 12 months than in those aged below 12 months [10 (2.06\%) vs. 1 (0.64\%)]. The prevalence of infection was significantly higher in female animals than in male animals $(p<0.05)$. However, no significant difference was found between the rates in the 2 age groups or in different seasons. While the infections were detected in several visceral organs, no significant difference was found between their infection rates.

Tables 1-4 summarize the prevalence of the mentioned metacestode based on the infected organs, age of the cattle, assessment time (season), and sex of the cattle, respectively. 
Table 2. Prevalence of Cysticercus bovis in different age groups of slaughtered cattle

\begin{tabular}{|l|c|c|c|}
\hline Age & $\begin{array}{c}\text { No. of } \\
\text { examined } \\
\text { cattle }\end{array}$ & $\begin{array}{c}\text { No. of } \\
\text { infected } \\
\text { cattle (\%) }\end{array}$ & $\mathbf{p}$ \\
\hline$<12$ months & 155 & $1(0.64 \%)$ & $\mathrm{p}>0.05$ \\
\hline$\geq 12$ months & 485 & $10(2.06 \%)$ & \\
\hline Total & 640 & $11(1.71 \%)$ & \\
\hline
\end{tabular}

Table 3. Prevalence of Cysticercus bovis in cattle slaughtered during various seasons

\begin{tabular}{|l|c|c|c|}
\hline Season & $\begin{array}{c}\text { No. of } \\
\text { examined } \\
\text { cattle }\end{array}$ & $\begin{array}{c}\text { No. of } \\
\text { infected } \\
\text { cattle (\%) }\end{array}$ & p \\
\hline Spring & 160 & $5(0.78 \%)$ & $\mathrm{p}>0.05$ \\
\hline Summer & 160 & $3(0.46 \%)$ & \\
\hline Fall & 160 & $2(0.31)$ & \\
\hline Winter & 160 & $1(0.15 \%)$ & \\
\hline Total & 640 & $11(1.71 \%)$ & \\
\hline
\end{tabular}

Table 4. Prevalence of Cysticercus bovis in different sexes of slaughtered cattle

\begin{tabular}{|l|c|c|c|}
\hline Sex & $\begin{array}{c}\text { No. of } \\
\text { examined } \\
\text { cattle }\end{array}$ & $\begin{array}{c}\text { No. of } \\
\text { infected } \\
\text { cattle (\%) }\end{array}$ & p \\
\hline Male & 425 & $3(0.70 \%)$ & $\mathrm{p}<0.05$ \\
\hline Female & 215 & $8(3.72 \%)$ & \\
\hline Total & 640 & $11(1.71 \%)$ & \\
\hline
\end{tabular}

\section{DISCUSSION}

C. bovis is the larval stage of T. saginata, which is an important intestinal parasite in humans. The importance of $C$. bovis infection is less than that of $C$. cellulosae infection because $C$. cellulosae has fecal oral transmission; thus, it lead to ocular and neurocysticercosis and is therefore a major public health concern, particularly in developing countries $(4,14,15)$. However, according to our findings, the prevalence of $C$. bovis infection in the cattle in Tabriz was comparatively high (1.71\%). Garedaghi et al. (16) reported the prevalence of the parasite in Meshkinshahr, Iran, to be $3.0 \%$. They also found that the cysts have the greatest frequency $(36.6 \%)$ in the masseter muscles of the cattle. Few cysts existed in the intestinal mucosa $(0.1 \%)$ or other organs (16).

In the present study, the prevalence of the cysts was significantly higher in female cattle than in male cattle $(p<0.05)$. Although the prevalence of infection was higher in older cattle than in younger cattle $(2.06 \%$ in animals who were $\geq 12$ months old vs. $0.64 \%$ in animals who were $<12$ months old), there was no significant difference between the 2 age groups. In addition, while higher numbers of $C$. bovis cases were detected in warmer seasons (spring, summer, and falls), i.e., the minimum infection rate was seen in winter, no statistically significant difference existed between any of the 4 seasons. Oryan et al. (1) calculated the prevalence of $C$. bovis in Fars Province, Iran, to be $7.7 \%$. They suggested that the highest number of cysticerci is present in the cattle's shoulders (26.3\%), tongue (24.9\%), masseter muscles $(23.7 \%)$, and heart (23.4\%). The pharynx, esophagus, and diaphragm had the lowest infection rates $(0.9 \%, 0.5 \%$, and $0.4 \%$, respectively) (1). Apparently, the prevalence rate of $C$. bovis in the present study $(1.71 \%)$ was lower than the values reported by both Garedaghi et al. (16) and Oryan et al. (1) (16). Moreover, contrary to the findings of these studies, there was a notable difference between male and female cattle in our study $(p<0.05)$.

Several studies in other countries have sought to determine the prevalence of $C$. bovis infection in cattle. Similar to earlier reports in various endemic areas, we identified the masseter muscles, tongue, heart muscles, triceps muscles, and thigh muscles as the preferred areas (predilection sites) for the cysts causing bovine cysticercosis (17-19). A number of factors such as muscle activity, animal's age, and geographical area seem to determine the predilection sites in slaughtered cattle $(18,20)$. According to previous studies on cattle, the prevalence rate was $0.142 \%$ in France (8), $1.6 \%$ in Zimbabwe (21), 2.3\% in India (22), $0.75 \%$ in Madagascar (23), $0.14 \%$ in Egypt (24), and 1.2\% in Mexico (25). These different rates can be attributed to several factors such as dissimilar climatic conditions, personal hygiene, number of collected sample, control measures, education level, and eradication programs in different countries. The habit of eating raw beef and backyard slaughter may have contributed to the prevalence of bovine cysticercosis in the cattle in Tabriz.

\section{CONCLUSION}

The results of the present study confirmed cysticercosis to be endemic in the cattle of Tabriz. Eradication of bovine cysticercosis requires cooperation between public health and veterinary officials. Meanwhile, public health education is considered to be the key factor for C. bovis control. Furthermore, detailed meat inspection is recommended to replace routine meat inspection. However, even if $C$. bovis infection was low in Tabriz, Iran, it could undoubtedly cause economic loss in the meat industry and health problems to the consumers. It is also important to conduct confirmation tests, i.e., to confirm/reject each positive finding on the slaughter line by pathohistological, immunochemical, or molecular tests. In this manner, after a certain period of time, we can draw conclusions about the real epidemiological situation of cattle cysticercosis in Tabriz and about the reliability of certain methods to monitor this disease.

Ethics Committee Approval: Ethics committee approval was not received for this study.

Informed Consent: Not required in this study.

Peer-review: Externally peer-reviewed.

Author Contributions: Concept - M.M.; Design - M.M.; Supervision M.M.; Funding - A.N.; Materials - H.R.; Data Collection and/or Processing - H.R.; Analysis and/or Interpretation - H.R.; Literature Review - M.M.; Writing - M.M.; Critical Review - J.A.; Other - J.A.

Conflict of Interest: The authors declare that they have no conflict of interest.

Financial Disclosure: This study was financially supported by Tabriz University. 
Etik Komite Onayı: Bu çalışma için etik komite onayı alınmamıştır.

Hasta Onamı: Bu çalışma için hasta onamına gerek yoktur.

Hakem Değerlendirmesi: Dış bağımsız.

Yazar Katkıları: Fikir - M.M.; Tasarım - M.M.; Denetleme - M.M.; Kaynaklar - A.N.; Malzemeler - H.R.; Veri Toplanması ve/veya İşlemesi - H.R.; Analiz ve/veya Yorum - H.R.; Literatür Taraması - M.M.; Yazıyı Yazan M.M.; Eleştirel İnceleme - J.A.; Diğer - J.A.

Çıkar Çatışması: Yazarlar çıkar çatışması bildirmemişlerdir.

Finansal Destek: Yazarlar bu çalışma için Tabriz Üniversitesi'nden finansal destek aldığını belirtmiştir.

\section{REFERENCES}

1. Oryan A, Moghaddar N, Gaur S. Taenia saginata cysticercosis in cattle with special reference to its prevalence, pathogenesis and economic implications in Fars Province of Iran. Veterinary Parasitology 1995; 57:319-27. [CrossRef]

2. Endrajat E. Statistisches uber die Rinderfinne in Iran. Deutsch Tierarztl Wochenschr 1938; 46: 472.

3. Khaniki GRJ, Raei M, Kia E, Haghi AM, Selseleh M. Prevalence of bovine cysticercosis in slaughtered cattle in Iran. Tropical Anim Health Prod 2010; 42: 141-3. [CrossRef]

4. Pawlowski Z, Murrell K. Taeniasis and cysticercosis. New York: Marcel Dekker Inc.; 2000.

5. V Silva C, M Costa-Cruz J. A glance at Taenia saginata infection, diagnosis, vaccine, biological control and treatment. Infectious Disorders-Drug Targets (Formerly Current Drug Targets-Infectious Disorders). 2010; 10: 313-21. [CrossRef]

6. Fahmy HA, Khalifa NO, EL-Madawy RS, Afify JS, Aly NS, Kandil OM. Prevalence of Bovine Cysticercosis and Taenia saginata in Man. Global Veterinaria 2015; 15: 372-80.

7. Li J, Guo E. Taenia saginata Infestation. New Engl J Med 2016; 374: 263. [CrossRef]

8. Dupuy C, Morlot C, Gilot-Fromont E, Mas M, Grandmontagne C, Gilli-Dunoyer $\mathrm{P}$, et al. Prevalence of Taenia saginata cysticercosis in French cattle in 2010. Veterinary Parasitology 2014; 203: 65-72. [CrossRef]

9. Gracey J, Collins D, Huey R. Diseases caused by helminth and arthropod parasites, Meat hygiene. 10th ed. UK: Saunders; 1999.

10. Ibrahim N, Zerihun F. Prevalence of Tania saginata cysticercosis in cattle slaughtered in Addis Ababa Municipal Abattoir, Ethiopia. Global Veterinaria 2012; 8: 467-71.

11. Kandil OM, Mahdy OA, Abou- Dobal SK, Mousa WM. Purification and characterization of the three larval taeniid antigens by gel filtration. Vet Med J 2004; 52: 449-56.
12. Oliveira HB, Machado GA, Mineo JR, Costa-Cruz JM. Taenia saginata metacestode antigenic fractions without affinity to concanavalin A are an important source of specific antigens for the diagnosis of human neurocysticercosis. Clin Vaccine Immunol 2010; 17: 638-44. [CrossRef]

13. Herenda DC, Chambers P. Manual on meat inspection for developing countries. Rome: Food \& Agriculture Org.; 1994.

14. Engels D, Urbani C, Belotto A, Meslin F, Savioli L. The control of human (neuro) cysticercosis: which way forward? Acta Tropica 2003; 87: 177-82. [CrossRef]

15. Phiri IK, Ngowi H, Afonso S, Matenga E, Boa M, Mukaratirwa S, et al. The emergence of Taenia solium cysticercosis in Eastern and Southern Africa as a serious agricultural problem and public health risk. Acta Tropica 2003; 87: 13-23. [CrossRef]

16. Garedaghi Y, Saber AR, Khosroshahi MS. Prevalence of Bovine Cysticercosis of Slaughtered Cattle in Meshkinshahr Abattoir, Iran. Journal of Animal and Veterinary Advances. 2012; 11: 785-8. [CrossRef]

17. Munyeme M, Munang'andu HM, Muma JB, Nambota AM, Biffa D, Siamudaala VM. Investigating effects of parasite infection on body condition of the Kafue lechwe (Kobus leche kafuensis) in the Kafue basin. BMC Res Notes 2010; 3: 346-51. [CrossRef]

18. Opara MN, Ukpong UM, Okoli IC, Anosike JC. Cysticercosis of slaughter cattle in southeastern Nigeria. Ann N Y Acad Sci 2006; 1081: 339-46. [CrossRef]

19. Pawlowski Z, Schultz MG. Taeniasis and cysticercosis (Taenia saginata). Adv Parasitol 1972; 10: 269-343. [CrossRef]

20. Minozzo JC, Gusso RLF, Castro EAd, Lago O, Soccol VT. Experimental bovine infection with Taenia saginata eggs: recovery rates and cysticerci location. Brazilian Archives of Biology and Technology 2002; 45: 451-5. [CrossRef]

21. Sungirai $M$, Masaka $L, M b i b a ~ C$. The prevalence of Taenia saginata cysticercosis in the Matabeleland Provinces of Zimbabwe. Tropical animal health and production 2014; 46: 623-7. [CrossRef]

22. Pramanik A, Bhattacharyya $H$, Sengupta D. Occurrence of Cysticercus bovis in slaughtered cattle and buffaloes in Calcutta and its public health significance. Indian Journal of Animal Health 1984; 23 : 141-5.

23. Buchy P. Intestinal parasitoses in the Mahajanga region, west coast of Madagascar. Bull Soc Pathol Exot 2003; 96: 41-5.

24. Haridy F, Ibrahim B, Morsy T, Ramadan N. Human taenaisis and cysticercosis in slaughtered cattle, buffaloes and pigs in Egypt. J Egypt Soc Parasitol 1999; 29: 375-94.

25. Martínez-Maya JJ, de Aluja AS, Avila-Ramírez G, Aguilar-Vega L, Plancarte-Crespo A, Jaramillo-Arango CJ. Taeniosis and detection of antibodies against cysticerci among inhabitants of a rural community in Guerrero State, Mexico. Salud Publica Mex 2003; 45: 84-9. 